\title{
Development of foreign joint educational programs in the higher education system of the Republic of Uzbekistan
}

\author{
Aslitdin Nizamov ${ }^{1 *}$, Farhod Gaybullaev ${ }^{1}$, and Umida Zahidova ${ }^{1}$ \\ ${ }^{1}$ Bukhara engineering technological institute, Bukhara, Uzbekistan
}

\begin{abstract}
The article examines the experience of developing and implementing relatively new for higher education system of the Republic of Uzbekistan foreign joint educational programs. The factors contributing to their development, the problems arising during the implementation of programs are determined, and indicators characterizing their general trend are studied. As a result of studying the Geographical distribution of joint educational programs, implemented by higher education institutions of Uzbekistan with foreign partners, share of joint programs organized by specialties, of the geography of the countries that have established joint educational programs with Uzbekistan, the influence of the Uzbek mentality on the success of the implementation of programs are provided scientifically grounded proposals and recommendations for the development of joint educational programs with foreign universities.
\end{abstract}

\section{Introduction}

With the adoption of the new Law of the Republic of Uzbekistan "On Education"(2020), the rights and opportunities of higher education institutions of Uzbekistan to establish contacts with foreign universities and participate in international programs have been further expanded. This is leading to the rapid development of international relations, updating the content of education and the conduct of the educational process, and the introduction of new methods of university management.

Article 67 of this Law [1] legally stipulates that educational institutions shall carry out international cooperation with educational institutions and organizations of the relevant foreign countries through the introduction of Double Diploma programs.

It should be noted that the development of cooperation between higher education institutions and foreign educational institutions in the Republic of Uzbekistan, the implementation of measures to internationalize education began long ago, in particular, in recent years a number of decrees and resolutions were adopted by the President and the Government of the country. For example, in the "Concept of development of the higher education system of the Republic of Uzbekistan until 2030" [2] implementation of the following measures is planned: "expansion of training activities on the basis of joint educational programs with foreign higher education institutions, increasing the number of

* Corresponding author: buhibkol@mail.ru 
joint scientific conferences and seminars, implementation of international scientific and educational projects; establishment of branches of local higher education institutions in foreign countries, implementation of joint educational programs and training of personnel on the basis of joint educational programs in cooperation with foreign higher education institutions", and already in 16 universities until the 2018/2019 academic year, double degree programs were launched.

It is safe to say that in the coming years, the creation of such programs in Uzbekistan will accelerate due to a number of changes in the higher education system of Uzbekistan (transition to credit-module system, the formation of third generation universities, ranking universities, etc.). Therefore, in order to increase the effectiveness of the organization and implementation of joint educational programs in the higher education system of Uzbekistan, it is important to analyze them in depth and identify current problems and find solutions.

\section{Research methodology}

Analyzing the organization and implementation of joint educational programs in the higher education system of Uzbekistan on the basis of statistical indicators, conducting questionnaires and interviews to identify existing problems and development factors among the participants of the implemented programs.

\section{Research results}

According to the Ministry of Higher and Secondary Special Education of the Republic of Uzbekistan, in recent years the number of educational institutions that have established relations with foreign universities, including joint educational programs, is growing (see Table 1).

Table 1. Number of joint educational programs and educational institutions implemented with foreign universities in Uzbekistan.

\begin{tabular}{|c|c|c|c|}
\hline & $\begin{array}{c}\mathbf{2 0 1 8 / 2 0 1 9} \\
\text { academic year }\end{array}$ & $\begin{array}{c}\mathbf{2 0 1 9 / 2 0 2 0} \\
\text { academic year }\end{array}$ & $\begin{array}{c}\mathbf{2 0 2 0} / \mathbf{2 0 2 1} \\
\text { academic year }\end{array}$ \\
\hline $\begin{array}{c}\text { Number of local higher } \\
\text { education institutions }\end{array}$ & $39(90)^{*}$ & $45(93)$ & $58(99)$ \\
\hline $\begin{array}{c}\text { The total number of joint } \\
\text { educational programs, }\end{array}$ & 256 & 298 & 387 \\
\hline
\end{tabular}

* The total number of higher education institutions in parentheses, including branches.

In the 2018/2019 academic year, 39 (43\%) out of 90 local universities (including branches) operating in Uzbekistan implemented joint educational programs, while in the 2019/2020 academic year, 45 out of 93 local universities (48\%), 2020/2021 In 2012, 58 out of 99 universities (58\%) implemented bilateral diploma programs. The fact that the share of universities involved in joint educational programs is growing from year to year (from $43 \%$ to $58 \%$ ) indicates that this area is one of the priorities of state education policy and the strengthening of government support measures. As a result, the total number of joint educational programs has increased from 256 to $387(151.2 \%)$. At the same time, the number of educational programs per educational institution increased from 6.5 in the $2018 / 2019$ academic year to 6.8 in the $2020 / 2021$ academic year, which indicates that new programs are being developed in the universities where the joint educational programs are implemented. 
In the 2020/2021 academic year, compared to the 2018/2019 academic year, joint bachelor's degree programs increased by $51.1 \%$, while master's specialties increased by $51.3 \%$ over the same period, indicating a high need for master's degree programs (see Figure 1).

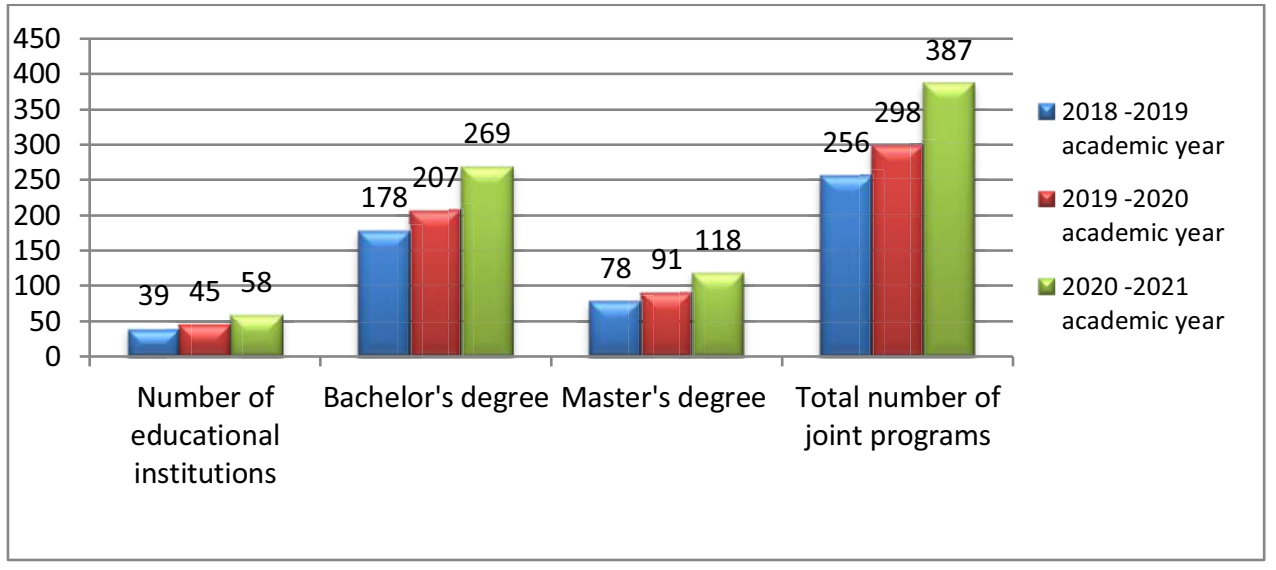

Fig. 1. Trends in the implementation of joint educational programs in higher education institutions of Uzbekistan*

*Calculated by the authors on the basis of the official websites of higher education institutions of Uzbekistan

Our research shows that the universities of Uzbekistan, which implement the largest number of bilateral diploma programs with foreign universities, in the 2020/2021 academic year are located in Tashkent (41.4\% of 24 universities) and Samarkand region $(13.8 \%$ of 8 universities).

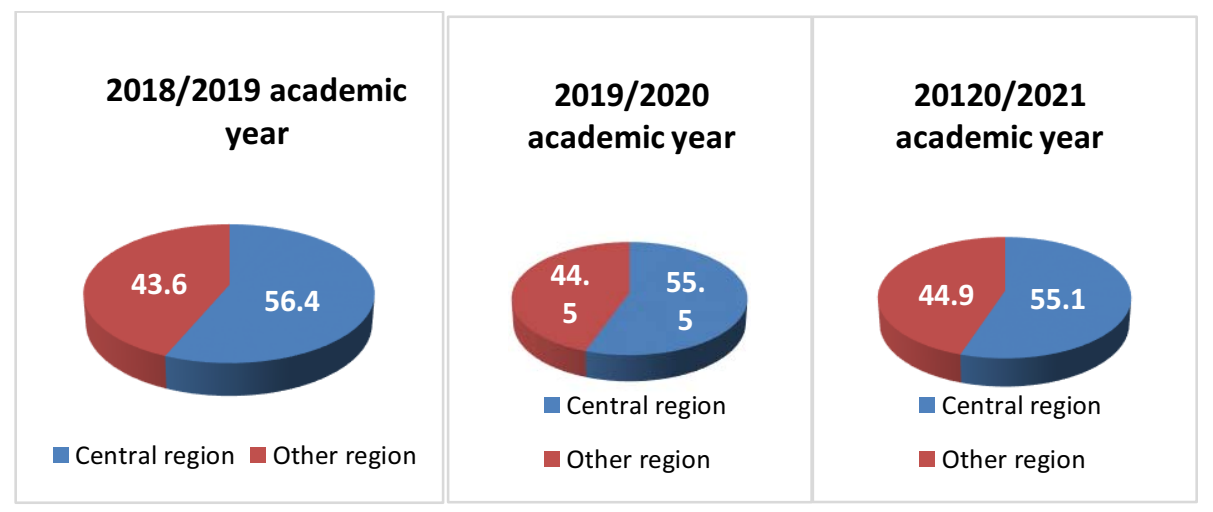

Fig. 2. Distribution of the created joint educational programs on territories of Uzbekistan*

*Calculated by the authors on the basis of the official websites of higher education institutions of Uzbekistan

These two regions account for the majority of foreign joint educational programs organized in the republic. In particular, in the 2018/2019 academic year, their share accounted for $56.4 \%$ of total programs, in the $2019 / 2020$ academic year this figure decreased to $55.5 \%$, and in the 2020/2021 academic year to $55.1 \%$ (Figure 2). This suggests that the focus on creating joint education programs is shifting more from the center to other 
regions. Nevertheless, more than half of the programs remain in the contribution of these two regions.

In other regions, the distribution of joint programs is 3, only in Navoi region and Surkhandarya region - 2, in Namangan region - 1 (Table 2).

Table 2. Geographical distribution of joint educational programs of Uzbek universities with foreign partners.

\begin{tabular}{|c|l|c|c|c|c|}
\hline № & Provinces & $\begin{array}{c}2018 / 2019 \\
\text { academic } \\
\text { year }\end{array}$ & $\begin{array}{c}2019 / 2020 \\
\text { academic } \\
\text { year }\end{array}$ & $\begin{array}{c}2020 / 2021 \\
\text { academic } \\
\text { year }\end{array}$ & $\begin{array}{c}2020 / 2021 \\
\text { weight in the } \\
\text { academic year }\end{array}$ \\
\hline 1 & Tashkent city & 17 & 19 & 24 & 41.38 \\
\hline 2 & Samarkand region & 5 & 6 & 8 & 13.79 \\
\hline 3 & Jizzakh Province & 1 & 2 & 3 & 5.17 \\
\hline 4 & Andijan region & 2 & 2 & 3 & 5.17 \\
\hline 5 & Bukhara region & 2 & 2 & 3 & 5.17 \\
\hline 6 & AR Karakalpakstan & 2 & 2 & 3 & 5.17 \\
\hline 7 & Kashkadarya region & 2 & 2 & 3 & 5.17 \\
\hline 8 & Namangan region & 1 & 1 & 1 & 1.72 \\
\hline 9 & Surkhandarya region & 1 & 1 & 2 & 3.45 \\
\hline 10 & Navoi region & 2 & 2 & 2 & 3.45 \\
\hline 11 & Fergana region & 2 & 3 & 3 & 5.17 \\
\hline 12 & Khorezm region & 2 & 3 & 3 & 5.17 \\
\hline & Total & 39 & 45 & 58 & 100 \\
\hline
\end{tabular}

If we analyze the distribution of joint educational programs by areas, we will witness the following situation.

The analysis shows that in the total number of joint curricula in the 2018/2019 academic year, the share of the humanities and social, economic and legal disciplines was higher due to the areas of pedagogy $(16.4 \%)$ and economics $(20.3 \%)$.. This trend is explained by the advantage of the new curricula to start in areas that do not require additional special laboratories and equipment. In recent years, we have seen an increase in the share of the manufacturing and technical sector $(7.9 \%)$ and the health sector $(0.5 \%)$, due to a decrease in other sectors.

The analysis shows that in the total number of joint curricula in the 2018/2019 academic year, the share of the humanities and social, economic and legal disciplines was higher due to the areas of pedagogy (16.4\%) and economics (20.3\%). This trend is explained by the advantage of the new curricula to start in areas that do not require additional special laboratories and equipment. In recent years, we have seen an increase in the share of the manufacturing and technical sector $(7.9 \%)$ and the health sector $(0.5 \%)$, due to a decrease in other sectors. The study of joint curricula in the field of education allows to identify positive trends as well as shortcomings [6]. For example, the selection of joint programs does not always focus on training qualified personnel in areas that are a priority for Uzbekistan. In our opinion, the priority is to further develop foreign cooperation in the fields of mathematics and natural sciences, communications and information, telecommunications technology, robotics, agriculture, forestry and fisheries, veterinary medicine, irrigation and land reclamation. Also There are still not enough programs in the field of health care. 
Table 3. Distribution of joint educational programs by fields and directions of education.

\begin{tabular}{|c|c|c|c|c|c|c|}
\hline № & Field of education & Code & $\begin{array}{l}\text { 2018/2019 } \\
\text { academic } \\
\text { year }\end{array}$ & $\begin{array}{l}\text { 2019/2020 } \\
\text { academik } \\
\text { year }\end{array}$ & $\begin{array}{l}\text { 2020/2021 } \\
\text { academik } \\
\text { year }\end{array}$ & $\begin{array}{c}2020 / 2021 \\
\text { compared to } \\
\text { the total of the } \\
\text { year } \\
\%\end{array}$ \\
\hline \multicolumn{2}{|c|}{ Humanitarian field } & & 51 & 68 & 89 & 23 \\
\hline 1 & Pedagogy & 5110000 & 42 & 53 & 66 & 17.05 \\
\hline 2 & Humanities & 5120000 & 1 & 1 & 2 & 0.52 \\
\hline 3 & Mathematics & 5130000 & 2 & 4 & 6 & 1.55 \\
\hline 4 & Natural sciences & 5140000 & & & 1 & 0.26 \\
\hline 5 & Art & 5150000 & & 2 & 4 & 1.03 \\
\hline 6 & $\begin{array}{l}\text { Sociology and } \\
\text { psychology }\end{array}$ & 5210000 & 6 & 8 & 10 & 2.58 \\
\hline 7 & $\begin{array}{l}\text { Journalism and } \\
\text { information }\end{array}$ & 5220000 & & & & \\
\hline \multicolumn{2}{|c|}{$\begin{array}{l}\text { Social sphere, economy and } \\
\text { law }\end{array}$} & & 53 & 57 & 91 & 23.5 \\
\hline 8 & Economy & 5230000 & 52 & 55 & 88 & 22.74 \\
\hline 9 & Law & 5240000 & 1 & 2 & 3 & 0.78 \\
\hline \multicolumn{2}{|c|}{$\begin{array}{l}\text { Production and technical } \\
\text { sphere }\end{array}$} & & 122 & 132 & 154 & 39.8 \\
\hline 10 & Engineering work & 5310000 & 36 & 38 & 52 & 13.44 \\
\hline 11 & $\begin{array}{l}\text { Production technologies } \\
-\end{array}$ & 5320000 & 26 & 30 & 33 & 8.53 \\
\hline 12 & $\begin{array}{l}\text { Computer technology } \\
\text { and informatics }\end{array}$ & 5330000 & 48 & 50 & 51 & 13.18 \\
\hline 13 & $\begin{array}{l}\text { Architecture and } \\
\text { construction }\end{array}$ & 5340000 & 6 & 6 & 8 & 2.07 \\
\hline 14 & $\begin{array}{l}\text { Communication and } \\
\text { information, } \\
\text { telecommunication } \\
\text { technologies }\end{array}$ & 5350000 & 6 & 8 & 10 & 2.58 \\
\hline \multicolumn{2}{|c|}{$\begin{array}{l}\text { Agriculture and water } \\
\text { management }\end{array}$} & & 6 & 9 & 12 & 3.1 \\
\hline 15 & $\begin{array}{l}\text { Agriculture, forestry } \\
\text { and fisheries }\end{array}$ & 5410000 & 1 & 1 & 1 & 0.26 \\
\hline 16 & $\begin{array}{l}\text { Management in } \\
\text { agriculture }\end{array}$ & 5420000 & & 1 & 1 & 0.26 \\
\hline 17 & Agricultural machinery & 5430000 & 2 & 3 & 5 & 1.29 \\
\hline 18 & Veterinary & 5440000 & 2 & 3 & 4 & 1.03 \\
\hline 19 & $\begin{array}{l}\text { Irrigation and } \\
\text { reclamation }\end{array}$ & 5450000 & 1 & 1 & 1 & 0.26 \\
\hline \multicolumn{2}{|c|}{ Health and Social Welfare } & & 8 & 8 & 10 & 2.6 \\
\hline 20 & health care & 5510000 & 8 & 8 & 10 & 2.58 \\
\hline 21 & Social security & 5520000 & & & & \\
\hline \multicolumn{2}{|c|}{ Services } & & 16 & 24 & 31 & 8.0 \\
\hline 22 & Service sector & 5610000 & 7 & 10 & 15 & 3.88 \\
\hline 23 & Transport & 5620000 & 1 & 1 & 2 & 0.52 \\
\hline 24 & $\begin{array}{l}\text { Environmental } \\
\text { protection }\end{array}$ & 5630000 & 5 & 8 & 9 & 2.33 \\
\hline 25 & Life safety & 5640000 & 1 & 1 & 1 & 0.26 \\
\hline \multirow[t]{2}{*}{26} & Military education & 5650000 & 2 & 4 & 4 & 1.03 \\
\hline & Total & & 256 & 298 & 387 & 100 \\
\hline
\end{tabular}




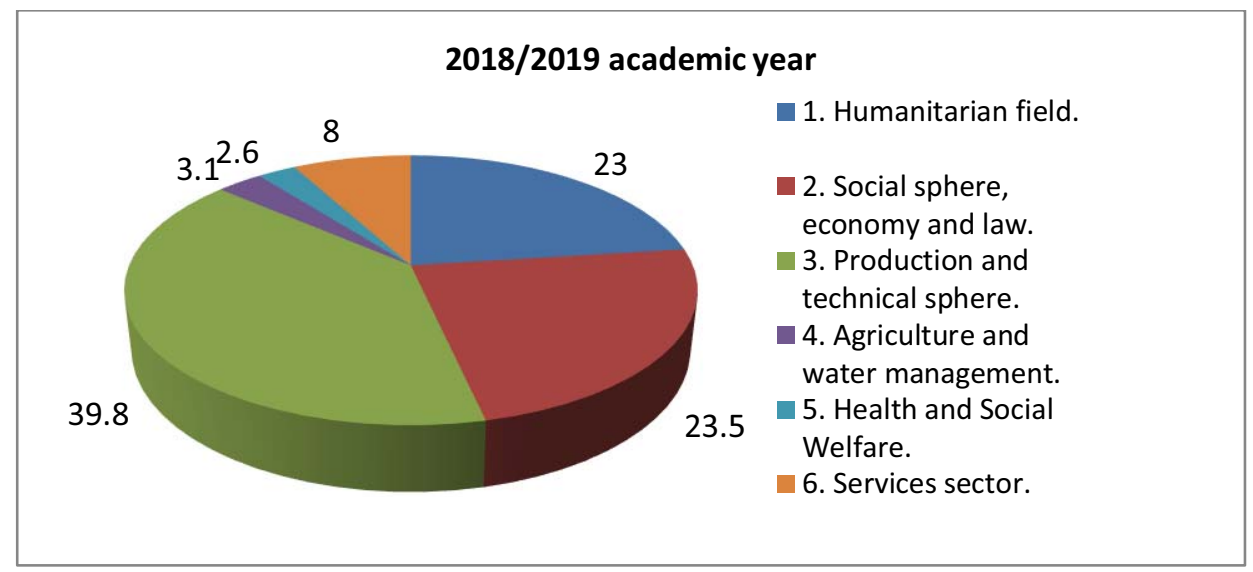

a)

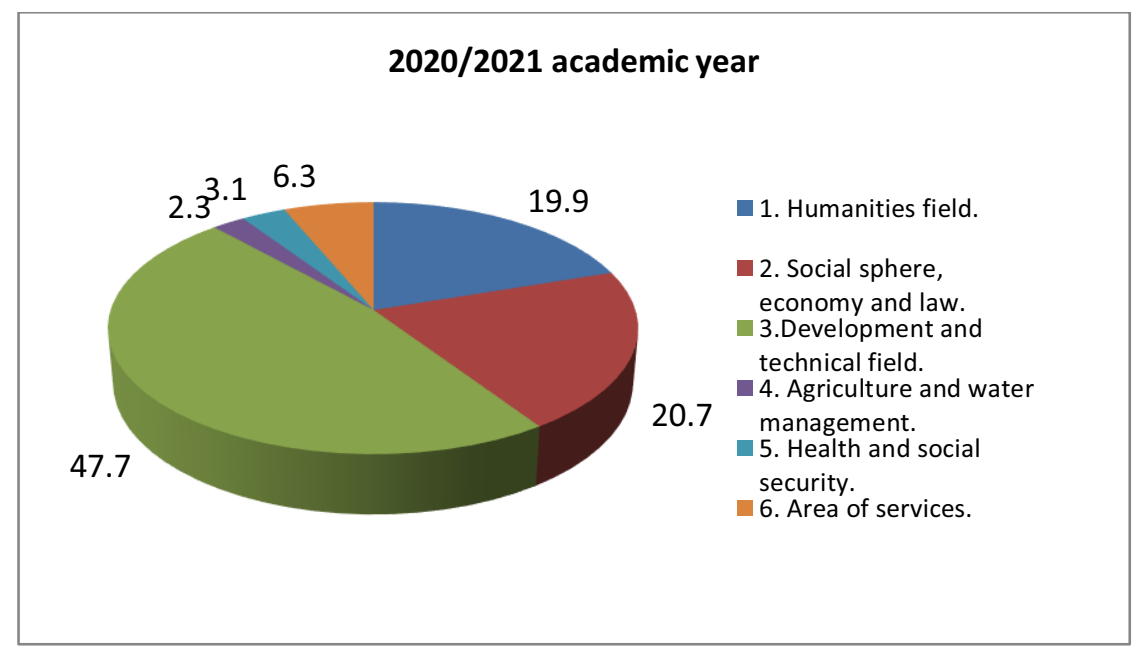

b)

Fig. 3. a) and- b) Comparison of the weight of joint curricula created in the field of education in the 2018/2019 and 2020/2021 academic years

Table 4. Trends in the weight of joint programs in the field of education*.

\begin{tabular}{|c|l|c|c|c|}
\hline № & Field of education & $\begin{array}{c}2018 / 2019 \\
\text { academic year }\end{array}$ & $\begin{array}{c}2020 / 2021 \\
\text { academic year }\end{array}$ & $\begin{array}{c}\text { The difference } \\
(+,-)\end{array}$ \\
\hline 1 & Humanities field & 23 & 19.9 & -3.1 \\
\hline 2 & $\begin{array}{l}\text { Social sphere, economy and } \\
\text { law }\end{array}$ & 23.5 & 20.7 & -2.8 \\
\hline 3 & $\begin{array}{l}\text { Development and technical } \\
\text { field }\end{array}$ & 39.8 & 47.7 & +7.9 \\
\hline 4 & $\begin{array}{l}\text { Agriculture and water } \\
\text { management }\end{array}$ & 3.1 & 2.3 & -0.8 \\
\hline 5 & Health and social security & 2.6 & 3.1 & +0.5 \\
\hline 6 & Area of services & 8 & 6.3 & -1.7 \\
\hline
\end{tabular}

*Calculated by the authors on the basis of the official websites of higher education institutions of Uzbekistan 
When choosing and implementing the topic of joint educational programs, it is important to establish cooperation with universities of countries that are leading in a particular field of science [9]. This requires an analysis of the geography of universities with bilateral diploma programs.

Table 5. Geography of countries implementing joint educational programs with Uzbek universities*.

\begin{tabular}{|c|c|c|c|c|c|}
\hline № & Countries & $\begin{array}{c}\text { Number } \\
\text { of } \\
\text { programs }\end{array}$ & $\begin{array}{c}\text { Relative } \\
\text { weight, } \\
\%\end{array}$ & $\begin{array}{l}\text { Since then, it has } \\
\text { entered the top } \\
\text { thousand (top- } \\
1000 \text { ) in the } \\
\text { ranking of the } \\
\text { world's } \\
\text { universities }\end{array}$ & $\begin{array}{c}\text { The weight } \\
\text { of } \\
\text { universities } \\
\text { included in } \\
\text { the top- } \\
1000 \%\end{array}$ \\
\hline 1 & Russian Federation & 186 & 48.06 & 5 & 2.6 \\
\hline 2 & Republic of Belarus & 121 & 31.27 & 2 & 1.65 \\
\hline 3 & USA & 11 & 2.84 & 3 & 27.27 \\
\hline 4 & Republic of China & 9 & 2.33 & 4 & 44.4 \\
\hline 5 & Poland & 9 & 2.33 & - & 0 \\
\hline 6 & $\begin{array}{l}\text { Republic of South } \\
\text { Korea }\end{array}$ & 8 & 2.07 & 3 & 37.5 \\
\hline 7 & Israel & 7 & 1.81 & 1 & 14.28 \\
\hline 8 & Ukraine & 6 & 1.55 & - & 0 \\
\hline 9 & Latvia & 4 & 1.03 & 2 & 50.0 \\
\hline 10 & Malaysia & 4 & 1.03 & 1 & 25.0 \\
\hline 11 & Austria & 3 & 0.78 & 1 & 33.3 \\
\hline 12 & $\begin{array}{l}\text { Federal Republic of } \\
\text { Germany }\end{array}$ & 3 & 0.78 & 1 & 33.3 \\
\hline 13 & France & 3 & 0.78 & - & 0 \\
\hline 14 & India & 3 & 0.78 & - & 0 \\
\hline 15 & Turkey & 2 & 0.52 & - & 0 \\
\hline 16 & Bulgaria & 2 & 0.52 & 2 & 100.0 \\
\hline 17 & Kingdom of Thailand & 2 & 0.52 & - & 0 \\
\hline 18 & Indonesia & 1 & 0.26 & - & 0 \\
\hline 19 & Slovak Republic & 1 & 0.26 & 1 & 100.0 \\
\hline 20 & Hungary & 1 & 0.26 & - & 0 \\
\hline 21 & Finland & 1 & 0.26 & - & 0 \\
\hline & Total & 387 & 100.00 & 25 & 6.45 \\
\hline
\end{tabular}

*Calculated by the authors on the basis of the official websites of higher education institutions of Uzbekistan

Among countries with joint educational programs with Uzbekistan, the Russian Federation is in the lead (48.06\%), followed by the Republic of Belarus $(31.27 \%)$, and the United States is in third place with a slight difference from the rest $(2.84 \%)$. The leading position of higher education institutions in Russia and Belarus can be explained by the closeness of peoples and the existence of a single unifying language. At the same time, the main motivating factor may have been the close cooperation with Russian and Belarusian universities in the past and the formation of a friendly and reliable partner. If we analyze the geographical location of the partners, we can see among the partners representatives of the European countries, including the former socialist countries, whose level of development is not yet far ahead of us, the of the East countries, the Scandinavian state and the American continent. It covers a total of 21 countries around the world, and there is great potential for further expansion of geography. 
In our opinion, the selection of partners should be based not only on friendly relations, ease of cooperation, but also on the criteria that ensure the effectiveness of joint educational programs [7].

When cooperating in the field of education, it is necessary to make sure that the partner university is one of the top 1000 higher education institutions in the ranking of higher education institutions published by the internationally recognized QS - Quacquarelli Symonds World University Rankings (official website: www.topuniversities.com). Of the partner universities in the established joint education programs, only $25(6.45 \%)$ are famous universities in the top 1,000 .

Although $79.3 \%$ of the organized joint programs are in the universities of the Russian Federation and the Republic of Belarus, only $4.25 \%$ of them are in the top thousand in the world rankings. We believe that the development of bilateral diploma programs with leading foreign higher education institutions in the field of science would be of great importance to improve the quality of education in local universities, improve university governance, accelerate the transformation process [8].

Table 6. The ratio of languages of instruction accepted in joint programs.

\begin{tabular}{|l|l|c|c|}
\hline № & \multicolumn{1}{|c|}{$\begin{array}{c}\text { Languages of } \\
\text { instruction }\end{array}$} & $\begin{array}{c}\text { Number of } \\
\text { programs }\end{array}$ & $\begin{array}{c}\text { The weight in the total number of } \\
\text { applications, \% }\end{array}$ \\
\hline 1 & Russian & 324 & 83.7 \\
\hline 2 & English & 63 & 16.3 \\
\hline & Total & 387 & 100 \\
\hline
\end{tabular}

As can be seen from Table 2.5, in 83.7 percent of the joint curricula, Russian language was adopted as the languages of instruction. These educational programs are developed in cooperation with higher education institutions of the Commonwealth of Independent States (CIS), the Russian Federation, Belarus and the Republic of Ukraine. Only 16.3 percent of programs are organized in the world language - English. This indicates that there are still shortcomings in the learning of foreign languages.

Table 7. Indicators of students studying in joint educational programs.

\begin{tabular}{|l|c|c|c|}
\hline \multicolumn{1}{|c|}{ Indicators } & $\begin{array}{c}2018 / 2019 \\
\text { academik } \\
\text { year }\end{array}$ & $\begin{array}{c}2019 / 2020 \\
\text { academic } \\
\text { year }\end{array}$ & $\begin{array}{c}2020 / 2021 \\
\text { academic year }\end{array}$ \\
\hline Total number of higher education students & 344790 & 468399 & 590077 \\
\hline $\begin{array}{l}\text { The total number of students enrolled in } \\
\text { joint education programs, including: }\end{array}$ & 1130 & 6255 & 8124 \\
\hline - male & 932 & 5103 & 6010 \\
\hline - female & 198 & 1152 & 2114 \\
\hline Female ratio, \% & 17.5 & 18.4 & 26.0 \\
\hline $\begin{array}{l}\text { The proportion of students enrolled in joint } \\
\text { education programs, \% }\end{array}$ & 0.33 & 1.33 & 1.37 \\
\hline
\end{tabular}

The proportion of girls enrolled in joint education programs averages $26 \%$. Compared to previous years, the coverage of girls is growing. If we take into account that an average of $38-40 \%$ of girls study in higher educational institutions of the republic, and this figure is planned to increase to $50 \%$ in the near future, this is still very low. Therefore, it is necessary to take measures to increase the number of girls involved in joint educational programs. 


\section{Discussion of research results}

The analysis shows that the joint educational programs in Uzbekistan have their own characteristics, which are related to the following:

- related to the peculiarities of their occurrence (continuation of cooperation in the framework of international programs, development of personal contacts);

- related to lack of funding local universities for development and implementation of joint educational programs, especially to ensure mobility

- with the problem of comparability of the conditions of study and residence of foreign students;

- $\quad$ related to language problems;

- $\quad$ related to with the Uzbek mentality (parents do not send girls to study abroad).

\section{Conclusion}

The investigation shows that as a result of practical experience gained in the higher education system of Uzbekistan, a general understanding of joint educational programs developed within the framework of jointly developed (agreed) and integrated curricula has been formed.

This is a serious achievement of Uzbek universities, which have tried to break the usual stereotypes in the context of strict state standards, to take a flexible approach to solving problems of science and courses, to create completely new mechanisms to ensure the quality of education. At the same time, the participation of students and professors in the educational process in partner universities on the principle of bilateral diploma programs expands mobility.

Despite the high level of attention paid by universities to foreign joint educational programs in Uzbekistan, the number of students studying in these programs is still insufficient $(1,37 \%)$. To solve the identified problems, we recommend the following:

1. Increase this share to $5 \%$, focusing on priority masters and doctoral specialties when the choice of topics program, that need to develop the economy of Uzbekistan.

2. To establish cooperation with higher education institutions of the countries that leading in the certain field of science, including the expansion of cooperation with universities that are in the top thousand (top-1000) in the ranking of world universities.

3 . In order to increase the coverage of girls, taking into account the Uzbek mentality, we consider it advantageous to develop educational programs in areas more suitable for employment of women and the organization of distance learning in partner educational institutions.

4. The allocation of state grant quotas for low-income students.

At the same time, over time, these problems are gradually being addressed, and the practice of Uzbekistan is showing bright examples of foreign joint educational programs, which are becoming "growth points" of local universities, the basis for transformation and modernization.

\section{References}

1. Law of the Republic of Uzbekistan "On Education". National Database of Legislation, 24.09.2020, No. 03/20/637/1313.

2. Decree of the President of the Republic of Uzbekistan dated October 8, 2019 No PF5847 "On approval of the Concept of development of the higher education system of the Republic of Uzbekistan until 2030". 
3. N.M. Aksenova, A.A. Muravyova, O.N. Oleinikova, Internationalization, international integration and cooperation in the field of vocational education and training (M: Logos, 2013)

4. A.I. Gorylev, S.N. Kuznetsova, Bulletin of the Nizhny Novgorod University. N.I. Lobachevsky. Series: Social Sciences 1 (45) (2017)

5. J. Knight, The Boston College centre for international higher education 69, 4-5 (2012)

6. J. Knight, Doubts and Dilemmas with Double Degree Programs // [Electronic resource]. - Access mode: http://www.ecahe.eu/w/images/e/e6/

Doubts_and_Dilemmas_with_Double_Degree_Programs.pdf

7. A. Nizamov, Sh.A. Rakhmatov, R.Kh. Alimova, ACADEMICIA An International Multidisciplinary Research Journal (Double Blind Refereed \& Peer Reviewed Journal) 10, 11, 359-364 (2020)

8. A. Nizamov, Sh.A. Rakhmatov, Journal of Physics: Conference Series 1691 (2020)

9. A. Nizamov, Sh.K. Gafurova, "Academicia” An International Multidisciplinary Research Journal 10, 6, 1784-1796 (2020) 